\title{
28
}

\section{ROLE AND RESPONSIBILITIES OF THE BOARD}

\author{
Natalie Sykes
}

The main role and responsibility of the board is the overall management and oversight of the organisation, providing leadership within a framework of good governance and controls with careful risk management, at all times.

At the outset, the board provides continuity for the organisation by setting up the legal entity and representing the organisation, its products, and services, in front of its stakeholders.

A board's responsibilities will include determining the long-term aims of the organisation, providing leadership to achieve these aims, and establishing a supervisory process to ensure that the management of the organisation is effective as well as being accountable to its stakeholders.

\section{Setting the direction}

Once up and running, the board is responsible for setting the policies and direction of the organisation. It is responsible for setting the vision, mission, and values of the organisation as well as reviewing and evaluating opportunities and threats, and helping management determine the strategy and strategic options to be pursued. 
The board is charged with overseeing the development of goals and strategy as well as the implementation process in order to address any problems the organisation may have in growing within its competitive environment. The board should drive the organisation's strategy forward, ensuring that the organisation and its financial resources are properly applied in order to successfully implement the chosen strategic priorities. The directors are expected to lead by example and ensure that good standards of behaviour permeate throughout all levels of the organisation.

The board governs the overarching policies of the organisation, and any changes to these policies are subject to board approval and agreement. Changes in policies are formulated and agreed by the CEO and employees, often driven through a commitment to continuous improvement of the organisation.

\section{The right resources}

The board is responsible for ensuring that there are sufficient financial resources in order for the strategic priorities to be implemented and delivered. The board also has a responsibility to make sure there are the requisite skills and experience within the board and executive team in order to oversee and execute strategy delivery. A large part of this obligation rests with the careful selection, appointment, and ongoing performance evaluation of the CEO as well as the careful ongoing evaluation that the board directors' skills are those required to bring strategic success to the organisation.

The way in which the board governs its relationship with the CEO is an important part of the overall governance of the organisation, which is also directed and set by the board. The dynamics between the chair and CEO are vital to board functionality, and it is important that these roles are separated, usually two different individuals with complementary skill sets. The chair leads the board, whilst the CEO leads the organisation. In unusual circumstances, the chair may become an executive chair with executive powers for a defined period of time.

Stakeholders are placing increased importance on delivery of long-term economic success while at the same time developing an appropriate working culture, so that in times of stress, the organisation can be relied upon to maintain a resilient performance. The board and executive management 
must ensure that decisions around value creation and the organisation's value system and culture are fully integrated.

\section{Board oversight}

The board is responsible for identifying the nature and extent of the risks facing the organisation in achieving its strategic aims and the risks to its long-term viability. The board is tasked with overseeing the risk management process, information system, and appropriate internal controls to facilitate the proper functioning of the organisation. The directors should monitor the organisation's risk management and internal control system and carry out periodic reviews of their effectiveness.

The board also has a fiduciary duty to protect the organisation's assets and ensure they are in good order with appropriate measures being taken to safeguard these by having full awareness of threats, opportunities, weaknesses, and challenges. This is extremely important as each director has equal and shared liability should this duty not be appropriately discharged.

The board is also responsible for the appointment of auditors and for ensuring that the audit is performed in a timely manner each year while demonstrating that the organisation is a going concern and operating within the insolvency laws.

\section{Board operations}

The board also ensures that the organisation's obligations to its shareholders, investors, members, and all other stakeholders are widely understood and managed accordingly. The directors are tasked with providing information to give stakeholders a clear and broad view of solvency and liquidity, the company's risk management approach, and the long-term viability of the business. The board needs to ensure that communications to and from stakeholders are relevant, effective, and take into account their interests. Boards continually need to monitor and improve their own performance. This can be achieved through board evaluation and effectiveness reviews, which provide a powerful and valuable feedback mechanism for improving the functioning of the board, maximising strengths, and highlighting areas for further development. 
A survey of 1,100 directors from consultants McKinsey, ${ }^{1}$ revealed that of the three dimensions of board operations the survey covered, effective processes emerged as the most challenging. In comparing board dynamics between the executives and the board, dynamics within the board itself, and board processes, the directors stated that the biggest struggle was with establishing effective processes. The quality of induction training and ongoing access to development opportunities were also named as real areas for improvement.

Looking forward, no organisation is immune to the effects of pandemics, cybersecurity, digitisation, and geopolitical risks, so these topics should be part and parcel of every board's discussions. Because businesses evolve and potential disruptions can arise at any time, it is important that boards maintain an agile and flexible approach to their operations.

\section{Questions to ask}

\section{Setting the direction}

- Is the board determining the organisation's vision, mission, and values?

- Does the board support the vision, mission, and values?

- Is the strategic plan developed by executives and approved and adopted by the board?

- Does the board ensure the budget reflects the strategic priorities?

- How does the board measure the implementation of the strategy?

\section{Resources}

- Does the board ensure that the board composition reflects the strategic needs of the organisation?

- Does the board ensure the executive team has the necessary skills to execute the strategy?

- Does the board ensure the financial position is adequate to be able to execute the strategy?

- How does the board select, appoint, and terminate directors?

1 www.mckinsey.com/business-functions/strategy-and-corporate-finance/our-insights/ a-time-for-boards-to-act\#. 
- How would the board deal with an underperforming CEO?

- Does the board encourage challenge and constructive discussion prior to decisions?

\section{Board oversight}

- Does the board oversee the execution of a strategic plan?

- Does the board have procedures and policies in place for good financial oversight?

- Has the board appointed a well-functioning audit committee that manages the relationship with the external auditor?

- Does the board ensure a risk management policy is in place for the board to be able to perform risk oversight?

- Has the board adopted a conflict of interest policy?

- Does the board ensure good compliance with laws and regulations and regular compliance reporting to the board?

- Does the board ensure stakeholder engagement, management, and communications planning is in place?

- Does the board ensure that all stakeholders are mapped effectively?

- Does the board measure the organisation's social impact?

- Does the board performance manage executives?

\section{Board operations}

- Is the board focused on governance, not executive management?

- How does the board demonstrate its commitment to good governance?

- Does the board have clear roles and responsibilities between board and executives?

- Does the board have a committee structure in place to accommodate the organisational needs?

- How does the board decide what the delegated powers of authority should be?

- Does the board conduct board reviews on a regular basis?

- How does the performance of board members get evaluated?

- How is their underperformance addressed? 